\section{Resolution of 5-Nucleotidase of Sheep Brain from Non-specific Phosphatase and its Inhibition by Nucleoside-triphosphates}

THE occurrence of 5-nucleotidase ${ }^{1}$ in association with non-specific phosphatase has been known for a long time in mammalian tissues ${ }^{2,3}$, but no method for separation of the two activities has been reported for the central nervous system.

This communication describes the resolution of a specific 5-nucleotidase and a non-specific phosphatase from sheep brain homogenates, together with some properties of the former enzyme.

The 27,000g supernatant fluid of sheep brain homogenates in 0.9 per cent sodium chloride was brought to $p H \mathbf{H}$ with 1 normal acetic acid, and centrifuged at $10,000 \mathrm{~g}$. The supernatant fluid, adjusted to $p \mathrm{H} \mathbf{7 \cdot 4}$ with 0.5 normal sodium hydroxide, was precipitated with ammonium sulphate between 0.33 per cent and 0.52 per cent saturation, solubilized in the minimal volume of tris-hydrochloric acid buffer, 0.05 molar and $p H \mathbf{H} 7$, and dialysed overnight against distilled water. The extract was chromatographed on DEAE-'Sephadex' elution was by means of hydrochloric acid buffer 0.025

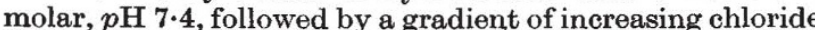
concentration. This procedure resulted in a complete resolution of the 5-nucleotidase from non-specific phosphatase, which were eluted respectively at 0.2 and at 0.4 molar sodium chloride.

For the non-specific phosphatase, the ratio of adenylie acid hydrolysis to phenylphosphoric acid hydrolysis was 1.5; therefore the specific activity of the nucleotidase during the purification procedure could be deduced by measuring the activity against adenosine-5-phosphate, and by subtracting that measured against phenylphosphoric acid multiplied by $1 \cdot 5$, rather than by simply subtracting that against phenylphosphoric acid.

Enzyme activities were tested by adding to $0.6 \mathrm{ml}$. of a 0.05 molar tris-hydrochloric acid buffer solution $p \mathbf{H ~ 7 . 4}$, $0.3 \mathrm{ml}$. of a 0.04 molar substrate solution, and $0.1 \mathrm{ml}$. of the DEAE eluate or enough extract from each purification step to give linear reaction rates with time and with protein concentration. After $5 \mathrm{~min}$ at $38^{\circ} \mathrm{C}$ the reaction was stopped with $1 \mathrm{ml}$. of 20 per cent trichloroacetic acid. Phosphate was determined ${ }^{4}$ on $1 \mathrm{ml}$. portions of the supernatant fluid. Proteins were determined according to Johnson ${ }^{5}$.

The enzyme unit is defined as the amount required to liberate 1 umole of inorganic phosphate in the above conditions. A summary of the purification procedure is given in Table 1.

The 5-nucleotidase has been found to be specific for adenosine-5-phosphate and inosine-5-phosphate. In contrast with other 5 -nucleotidases ${ }^{6-8}$, divalent cations were not required for maximal activity. Adenosine triphosphate, inosine triphosphate, uridine triphosphate and cytidine triphosphate were found to be potent inhibitors; the concentrations required to exert 50 per cent inhibition were $0.3,1,1.3$ and 5 umolar respectively. Guanosine triphosphate, bases, nucleosides, nucleoside-monophosphates and inorganic pyrophosphate up to $1 \mathrm{mmolar}$ were not inhibitory.

This communication confirms the distinct identities of 5-nucleotidase and non-specific phosphatase in the central nervous system, and suggests that the former enzyme may be regulated by intracellular adenosine triphosphate. Furthermore, the properties of the 5-nucleotidase suggest that the mclecule may be different from other 5-nucleotidases so far described.

This investigation was supported by a grant from the Impresa di Enzimologia of the Consiglio Nazionale delle Ricerche.

\section{P. L. Ipata}

Institute of Biological Chemistry,

University of Pisa,

Italy.

${ }^{1}$ Reis, J. L., Bull. Soc. Chim. Biol., 16, 385 (1934).

' Reis, J. L., Biochem. J., 48, 548 (1951).

${ }^{3}$ Fleischhacker, H. H., J. Ment. Sci., 84, 947 (1938).

' Fiske, C. H., and Subbarow, Y., J. Biol. Chem., 68. 357 (1925).

${ }^{5}$ Johnson, M. J., J. Biol. Chem., 137, 374 (1941).

-Moss, D. W., Nature, 209, 806 (1966).

' Heppel, L., and Hilmoe, R. J., J. Biol. Chem., 188, 665 (1951). s Nikol'bkaya, I. I., Kishina, O. S., and Tikhonenko, T. I., Biokhimiga, 80,
107 (1965).

\section{Androgenic Control of a Sex-dependent Protein in the Rat}

Proteinuria in the adult male rat has been recognized as a sex characteristic since $1933^{1}$. At first the source of the sex-related proteins was considered to be the prostate gland $^{1}$, but more recently evidence has suggested the kidneys ${ }^{2,3}$. These sites are likely because of the known anabolic effects of androgens on prostatic and renal tissues ${ }^{4,5}$.

Investigations of the urinary proteins of mice and rats $^{2}$ have demonstrated that they are actually of hepatic origin. A specific protein has been purified from male rat urine and shown to have a molecular weight of 26,400 and a hexose content of 6 per cent ${ }^{8}$. It has been described as $\alpha_{2 \mathrm{u}}$ in the immunoelectrophoretic nomenclature ${ }^{\circ}$ and shown to be present in normal male serum to the extent of less than $3 \mathrm{mg}$ per cent? ${ }^{\text {? }}$ Total nephrectomy resulted in a thirty-fold accumulation of $\alpha_{2 u}$ in $6 \mathrm{~h}$. This protein was synthesized in vitro in a perfused male liver at the rate of $0.18 \mathrm{mg} / \mathrm{g}$ of liver $/ \mathrm{h}$.

The hepatic synthesis of $\alpha_{2 u}$ may also come under androgenic control. A sex-related component has been separated from the total proteins of the male rat liver which is absent in the female ${ }^{10,11}$. Treatment of female rats with testosterone induced the hepatic synthesis of this protein. Liver slices from partially hepatectomized and castrated rats given testosterone propionate were found to incorporate glycine-1.14 C more rapidly than did those from similar but untreated animals ${ }^{12}$. No specific protein was investigated and the anabolic effect may reflect a general action of androgens on protein synthesis ${ }^{4,5}$.

A dependency of the urinary protein on the sex of the animal is shown by the paper electrophoretic patterns of Fig. 1. The $\alpha$-globulin region, which is the chief protein component of urine of male rats, was absent from the urine of females. The urinary proteins of the normal female rat appear to be derived mainly from the plasma; the chief component migrated in a similar fashion to serum albumin. Ovariectomized female rats (Sprague-Dawley), treated with 10-15 daily injections of testosterone propionate (1 mg/100 g of body weight), excreted a new component

Table 1. PURIFICATION OF 5-NUCLEOTIDASE FROM BHER BRAT

Extract
Step $127,000 g$ supernatant fluid
Step 2 pH 5 supernatant fluid
Step 3 Ammonium sulphate
fractionation
Step 4 DEAE 'Sephadex' column
(fraction eluted at $0 \cdot 2$ molar
sodium chloride)

$\begin{gathered}\text { Volume } \\ (\mathrm{ml} .)\end{gathered}$
400
336
72
44

$\begin{array}{ccc}\begin{array}{c}\text { Protein } \\ \text { (mg) }\end{array} & \begin{array}{c}\text { Specific 5-nucleotidase } \\ \text { Total } \\ \text { enzyme } \\ \text { (U) }\end{array} & \begin{array}{c}\text { Specific } \\ \text { activity } \\ \text { (J/mg) }\end{array} \\ \begin{array}{ccc}15,000 \\ 4,030\end{array} & \begin{array}{c}1,070 \\ 0.071\end{array} \\ 1,764 & 932 & 0.53 \\ & & \\ 61 \cdot 6 & 572 & 9.2\end{array}$

Yield
(per cent)
100
97
80
52

$\mathbf{P}$

Pactor
facation
$\begin{aligned} & 1 \\ & 3 \cdot 7 \\ & 7 \cdot 6\end{aligned}$

129

$\begin{array}{ccc}\begin{array}{c}\text { Non-8pecific phosphatase } \\ \text { Total } \\ \begin{array}{c}\text { enzyme } \\ \text { (U) }\end{array}\end{array} & \begin{array}{c}\text { Specific } \\ \text { activity } \\ \text { (U/mg) }\end{array} & \begin{array}{c}\text { Yield } \\ \text { (per cent) }\end{array} \\ 2,370 & 0.16 & 100 \\ 1,665 & 0.39 & 70 \\ 963 & 0.55 & 40\end{array}$

0

0 